\title{
THE CHALLENGE OF STRENGTHENING EQUALITY POLICIES WITHIN THE CONTEXT OF ARMED CONFLICT AND PEACE NEGOTIATIONS
}

\author{
Rakel Oion Encina*
}

University of the Basque Country

\begin{abstract}
The paper presents a piece of a $\mathrm{PhD}$ research project about the evolution of the armed conflict axis conflict within the equality policies of the national government of Colombia, from 1992 to 2018. One of the hypothesis that orientates the research is that equality and gender equity policies have lower status in comparison to other public policies, such as peace. The low status is reflected in the lack of resources destined to building up a strong public institution in charge of promoting women's rights, which could develop cross gender equality programs along with other ministries and public departments. It also focuses on the importance of the international law framework, such as the Beijing Platform and the United Nations Security Council resolutions on women, security and peace. Equality policies in Colombia have had an inconstant evolution. The public institution created for promoting them has been degrading in status, losing decision power and funding. The peace process has not always entailed the strengthening of public equality policies. On the contrary, in some legislations willing to promote peace agreements, equality policies have got no specific budget. Peace and equality are the two principles that governments have not built parallel. In addition, the gender mainstreaming approach in public policy has served to justify the lack of specific funding for the national institution responsible for promoting equality in the country and for the policies drafted.
\end{abstract}

Keywords: equality policies, women, gender, peace, armed conflict, Colombia

\section{Introduction}

In this article, I analyze the evolution of gender equality policies in Colombia during the period 1992-2018. The country has faced an armed conflict of more than fifty years during which it has promoted several peace processes. Since the nineties it has designed several national gender equity policies. My objective is to analyze the evolution of those policies and also pay attention to their development within the different peace processes in the country. For this aim I will analyze the following aspects: 1) Political party in the government; 2) Existing peace process; 3) Rank of the national public institution responsible for designing and implementing gender policies; 4) Budgetary autonomy and decision-making capacity of the institution; 5) Budget allocated for the implementation of the designed policy. To this end, I have reviewed the drafted policies, the governmental National Plans for Development, as well as other literature on the armed conflict in the country and the policies on peace and equality.

The article is divided into four sections. First, I will present the origin and evolution of the Colombian armed conflict, as well as the different peace processes promoted by the country's presidents. Next, I will introduce the international regulations for women's rights promotion and the development of equality policies, in particular, that referring to contexts of armed conflict. Next, I will go through the creation and evolution of the public institution responsible for promoting gender equality policies in Colombia, as well as the plans designed and the allocation of budget to them. Finally, I will offer some conclusions.

\section{Armed conflict and Peace processes in Colombia}

The alternating government of the liberal and conservative parties characterizes Colombia. This alternation constituted the general dynamics of the government of the country since its independence from Spain in 1810. 
The construction of the political adversary as an enemy (Rehm, 2014) and the use of violence for partisan purposes and repression of the social response to the imbalance of power, are at the root of the origin of the armed insurgencies of the mid-twentieth century (Barrios, 2016). In some groups women have come to constitute $40 \%$ of its bases (Sandino, former commandant of the FARC). Since the eighties different peace processes have been aimed at the demobilization of insurgencies. But they did not entail social reforms or the protection of the right to political participation. However, as a former member of the M-19 Movement pointed out, each process was an apprenticeship in the way of building peace agreements (Grabe, 2004).

The following table shows the presidents and political parties that have governed the country since 1978, as well as their peace policy in order to end the armed conflict.

Table 1. Peace policies in Colombia from 1978 until 2018

\begin{tabular}{|l|l|l|l|l|}
\hline Period & 1978-1982 & 1982-1986 & 1986-1990 & 1990-1994 \\
\hline President & César Turbay & BelisarioBetancur & Virgilio Barco & César Gaviria \\
\hline Political Party & Liberal & Conservative & Liberal & Liberal \\
\hline Peace Policy & $\begin{array}{l}\text { Law } 37 \text { of Amnesty. } \\
\text { Security Statute. }\end{array}$ & $\begin{array}{l}\text { Law 35 of Amnesty. } \\
\text { Peace agreements with } \\
\text { the ADO, some } \\
\text { sections of the ELN } \\
\text { and the FARC, 1984. }\end{array}$ & $\begin{array}{l}\text { Policy Pact for Peace } \\
\text { and Democracy, 1989. } \\
\text { Peace agreements with } \\
\text { the M-19, the Quintín } \\
\text { Lame, the CRS and } \\
\text { the EPL, 1990 }\end{array}$ & Constitution of 1991 \\
\hline
\end{tabular}

\begin{tabular}{|l|l|l|l|l|}
\hline Period & 1994-1998 & 1998-2002 & 2002-2010 & 2010-2018 \\
\hline President & Ernesto Samper & Andrés Pastrana & Álvaro Uribe & Juan Manuel Santos \\
\hline Political party & Liberal & Conservative & Conservative & Liberal \\
\hline Peace policy & & $\begin{array}{l}\text { Failed peace process } \\
\text { with the FARC }\end{array}$ & $\begin{array}{l}\text { Peace process with the } \\
\text { AUC, 2003 }\end{array}$ & $\begin{array}{l}\text { Peace agreement } \\
\text { with the FARC, 2016 } \\
\text { Current peace } \\
\text { process with the ELN }\end{array}$ \\
\hline
\end{tabular}

Source: Self-made.

In 1981, under the liberal government of César Turbay (1978-1982), the Amnesty Law 37 was approved. Nevertheless, this law was implemented along with another series of repressive measures (Chaparro, 2013) such as the Security Statute, which attributed broad powers to the armed forces (Cardona and González, 2016). The conservative government of Belisario Betancourt (1982-1986) approved another amnesty law, Law 35 of 1982. Betancourt promoted a peace and demobilization process, which was welcomed by the Workers' Self-Defense Movement (Movimiento de Autodefensa Obrera- ADO) and several fronts of the National Liberation Army (Ejercito de Liberación Nacional - ELN) and the Revolutionary Armed Forces of Colombia (Fuerzas Armadas Revolucionarias de Colombia - FARC). In 1985 the demobilized people created the left political party Patriotic Union (Unión Patriótica - UP). Leaders and representatives were all exterminated, from presidential, congressional and deputy candidates, to mayors, council members and grassroots militants. In 2014 the General Prosecutor of the Nation declared those acts as crimes against humanity, as they pursued the elimination of any possibility of political participation of the new opposition. 
In 1989 the liberal president Virgilio Barco approved the Political Pact for Peace and Democracy. The Congress passed Law 77 on pardon what enabled the signing of different peace agreements with some guerrillas: Movement April 19 (M-19), Quintin Lame Movement, People's Liberation Army (Ejercito Popular de Liberación - EPL) and Socialist Renewal Current (Corriente de Renovación Socialista - CRS) split from ELN. The M-19, Quintin Lame and CRS demobilized definitely. Neither a fraction of the EPL, nor the ELN and the FARC took part in those peace talks (Grabe, 2004). These demobilizations took place within the framework of the drafting of a new constitution for the country, approved in 1991, so that the demobilized groups could be present in the elaboration of the text. The new constitution generated political and social expectations for an inclusive country project for the most disadvantaged classes, indigenous peoples and women. The previous proceedings were accompanied by measures of pardon and amnesty. They benefited both insurgent actors, as well as state forces, which had also committed crimes against humanity (Chaparro, 2013). Women excombatants faced specific situations and gender difficulties during demobilization and reintegration (PIOM, 1999).

During the government of the liberal of Ernesto Samper, Law 418 of 1997 was passed. It recognized the guerrillas as political actors. This made the subsequent attempts of the government to hold peace dialogues with the insurgencies possible. During the period of Conservative President Andrés Pastrana, the failed talks in Caguán with the FARC took place. The FARC strengthened during that period. In this context, conservative President Andrés Uribe activated a national security plan to fight the guerrillas. On the other hand, he signed a demobilization agreement with the United Self-Defense Forces of Colombia (Autodefensas Unidas de Colombia - AUC), the paramilitary forces. Subsequently, he approved the controversial law Justice and Peace, with the aim of facilitating their reincorporation into civil life.

The current president Juan Manuel Santos, who had been Interior Minister during the previous government, approved the Law 1448 of 2011, on Victims and Land Restitution. The law dictated measures for attention, assistance and integral reparation of victims. To fulfill the law the Unique Registry of Victims (RegistroÚnico de Víctimas - RUV) was created. In February of 2018, the RUV has registered 8,632,032 victims: 994,063 victims of homicides, 168,899 people disappeared by force, 36,519 abducted, 10,748 tortured, 13,454 victims of antipersonnel mines, 84,265 victims of attacks and harassment, 8,556 children forcibly recruited, 7,344,917 forcibly displaced persons, 112,683 who lost their property, 6,023 were forced to abandon their lands and 24,533 victims of sexual violence. The first survey on the prevalence of sexual violence in the armed conflict revealed that $17.58 \%$ of women in areas with the presence of armed actors had suffered sexual violence by them. In only 9 years, 2001-2009, a total of 489,687 cases (Casa de la Mujer, 2011).

In 2012, the president began talks in Havana with the FARC. After four years the peace agreement was signed on August 24, 2016. The success of the dialogue, among other factors, was due to the important social support of the peace process. Women's movement played a key role, requiring the actors at the table to reach an agreement. They also achieved the inclusion of women representatives at the negotiating table; by the government, initially the High Councilor Nigeria Rementería and later Paulina Riveros, Director of Human Rights of the Ministry of the Interior and; by the FARC, commander Victoria Sandino. Women's movement also managed to create a Gender Subcommittee for the negotiating table, responsible for incorporating the gender approach into the points of the agreement.

The government, in order to get the biggest social support for the agreement called a plebiscite on October 2, 2016. With a participation of $37.43 \%$ of the population, the result was $49.78 \%$ in favor of the agreement and $50.21 \%$ against (National Registry of Civil Status). The region's most affected by the conflict registered a greater number of votes in favor of the agreement. The no's positions were not contrary to peace, but contrary to an agreement that, from conservative positions, was said to benefit the armed actors and that would put the viability of the family in Colombia at risk due to the "gender ideology" (Maria del Rosario Guerra, Senator of the Democratic Centre). The result entailed the revision of the text and its negotiation with the promoters of the 
«no». Finally, a new text was agreed, which was approved by the Senate and the House of Representatives on November 30, 2016.

The current government is holding peace talks with the ELN. In addition, it will still have to face the challenge the dismantling of the Criminal Bands (BACRIM) that emerged after the demobilization of the AUC. These actors occupy the areas abandoned by previous insurgencies, controlling illicit businesses such as drug trafficking (Prieto, 2016). The situation of human rights violations continues to be worrisome (Delegated Commission of the Basque Country, 2018). The country faces an economic culture of war that must be transformed in all its dimensions in order to achieve peace. According to the Institute of Studies for Development and Peace, since peace agreements, on the one hand, homicides related to the armed conflict have declined; on the other hand, murders of social leaders have increased. "Peace process generates a reordering of powers and territories and there are commanders (legal and illegal) who want to cover those territories. There is violence around the war economies of coca crops, drug trafficking routes, illegal mining and elements of political power" (Indepaz, 2018).

\section{International law regarding gender policies in contexts of armed conflict}

The main international tool for women's rights advance is the Convention on the Elimination of All Forms of Discrimination against Women (CEDAW) promulgated in 1979. Colombia signed it in 1999 and ratified it in 2007. That decade women's human rights begun to be more visible. In 1975 the United Nations proclaimed the Decade for the Advancement of Women, under the slogan Equality, Development and Peace. Four World Conferences on Women were held in 1975, 1980, 1985 and 1995. This led signatory States to design equality policies for women and to create institutions in charge of implementing and enforcing those policies (Garcia, 2003).

The Beijing Declaration and Platform for Action (BDPA) from the fourth World Conference on Women (1995) established institutional mechanisms for the advancement of women as a priority area of action. In this regard, it determined the following objectives: 1) Create or strengthen national mechanisms and other governmental bodies; 2) Integrate the gender perspective in legislation, policies, programs and public projects; and 3) Prepare and disseminate data disaggregated by sex, as well as information for planning and evaluation.

The Beijing Platform also developed a priority area of action on armed conflict, which set out five strategic objectives: 1) to protect the life and integrity of women, 2) to provide them with training and access to decisionmaking, 3) to facilitate their participation in non-violent conflict resolution, 4) to strengthen their expressions and promote their contributions and proposals for a culture of peace, and 5) to reduce military expenditures and troops.

On the other hand, resolutions of the United Nations Security Council on Women, Peace and Security must be mentioned. In 2000, the United Nations Security Council (UNSC) approved the Resolution 1325 on Women, Peace and Security. The UNSC later approved nine other complementary resolutions. To promote the implementation of Resolution 1325, the Secretary-General's report (S/2010/173) contained 26 indicators for follow-up. Those were organized around four dimensions: prevention, participation, protection, assistance and recovery. Several of the resolutions emphasize the importance of promoting the political participation of women, both in government bodies and legislative and constitutional reviews, as well as in peace negotiating teams. With regard to women's social promotion, they refer to the funding of programs and projects of government and civil entities concerning Women, Peace and Security.

\section{Institutional mechanism and equality policies in Colombia}

First sectorial equality policies in Colombia were set in the eighties, coinciding with the decade for the advancement of women, established by the UN. Within the Ministry of Agriculture, the Rural Women Office 
was created. The Policy on the Role of Rural Women in Agricultural Development was designed and given funding (CONPES 2109). The CONPES documents are those approved by the National Council of Economic and Social Policy. They specify the objectives of public policy and designate resources and officials responsible and for its implementation. Among the objectives of that policy were the strengthening of the peasant women's organization, the improvement of life quality and the achievement of the benefits of development for rural women. In this way, in 1984, the National Association of Peasant and Indigenous Women of Colombia (ANMUCIC) was established. It is one of the most important women's organizations in the country, with more than 22,000 affiliates (Oion, 2003). Many of its leaders were killed and threated. On the other hand, in 1988 the Colombian Family Welfare Institute (ICBF) implemented the Community Homes and Mothers Policy. The Family Welfare Homes (Hogares de Bienestar Familiar) program supported households, especially those headed by women taking care of their children (Londoño, 1995; Ocaña, 2009).

Next general public policies for the advance of women were drafted. The following table shows the institutional mechanisms created from 1992 until 2014, their decision-making autonomy and budget, the gender equity policies drafted, as well as the funding approved by the National Council of Economic and Social Policy (CONPES).

Table 2: Public institutions and gender policies for women's advance in Colombia (1992-2018)

\begin{tabular}{|c|c|c|c|c|c|}
\hline Period & 1990-1994 & 1994-1998 & 1998-2002 & 2002-2010 & 2010-2018 \\
\hline Party & Liberal & Liberal & Conservative & Conservative & Liberal \\
\hline $\begin{array}{l}\text { Rank of the } \\
\text { mechanism }\end{array}$ & $\begin{array}{l}\text { Presidential } \\
\text { Council for } \\
\text { Youth, Women } \\
\text { and the Family }\end{array}$ & $\begin{array}{l}\text { National } \\
\text { Direction for } \\
\text { Women's } \\
\text { Equity }\end{array}$ & $\begin{array}{l}\text { Presidential } \\
\text { Council for } \\
\text { Women's } \\
\text { Equity }\end{array}$ & $\begin{array}{l}\text { Presidential } \\
\text { Council for } \\
\text { Women's Equity }\end{array}$ & $\begin{array}{l}\text { High Presidential } \\
\text { Council for Women's } \\
\text { Equity, just to } 2014 \\
\text { Council for Women's } \\
\text { Equity }\end{array}$ \\
\hline $\begin{array}{l}\text { Decision- } \\
\text { making } \\
\text { power }\end{array}$ & $\begin{array}{l}\text { Decision- } \\
\text { making } \\
\text { autonomy and } \\
\text { budget }\end{array}$ & $\begin{array}{l}\text { Decision- } \\
\text { making } \\
\text { autonomy and } \\
\text { budget }\end{array}$ & $\begin{array}{l}\text { Dependent on } \\
\text { the Presidential } \\
\text { Office }\end{array}$ & $\begin{array}{l}\text { Dependent on the } \\
\text { Presidential } \\
\text { Office }\end{array}$ & $\begin{array}{l}\text { Dependent on the } \\
\text { Presidential Office }\end{array}$ \\
\hline $\begin{array}{l}\text { Drafted } \\
\text { Gender } \\
\text { Equity } \\
\text { Policies }\end{array}$ & $\begin{array}{l}\text { 1) Integral } \\
\text { Policy for } \\
\text { Women, } 1992 \\
\text { 2) Policy of } \\
\text { Equity and } \\
\text { Participation of } \\
\text { Women, } 1994\end{array}$ & $\begin{array}{l}\text { 3) Adjustments } \\
\text { to the Policy of } \\
\text { Equity and } \\
\text { Participation of } \\
\text { Women, } 1997\end{array}$ & $\begin{array}{l}\text { 4) I National } \\
\text { Plan for } \\
\text { Women's } \\
\text { Equality, } 1999 \\
\text { (never } \\
\text { approved) }\end{array}$ & $\begin{array}{l}\text { 5) National } \\
\text { Policy "Women } \\
\text { Builders of Peace } \\
\text { and } \\
\text { Development", } \\
2003\end{array}$ & $\begin{array}{l}\text { 6) Guidelines of the } \\
\text { National Public } \\
\text { Policy of Gender } \\
\text { Equity for Women, } \\
2012 \\
\text { 7) Guidelines for the } \\
\text { Prevention of Risks, } \\
\text { Protection and } \\
\text { Guarantee of Rights } \\
\text { of Women Victims of } \\
\text { Armed Conflict }\end{array}$ \\
\hline $\begin{array}{l}\text { Allocated } \\
\text { budget by } \\
\text { the } \\
\text { CONPES }\end{array}$ & $\begin{array}{l}2626 \text { of } 1992 \\
44 \text { million COP } \\
2726 \text { of } 1994 \\
\text { Undefined }\end{array}$ & $\begin{array}{l}2941 \text { of } 1997 \\
\text { Undefined }\end{array}$ & & & $\begin{array}{l}161 \text { of } 2013 \\
3,414,999 \text { million } \\
\text { COP }(2013-2016) \\
3784 \text { of } 2013 \\
3.2 \text { billion COP } \\
(2013-2015)\end{array}$ \\
\hline
\end{tabular}

Source: Self-made. 
From 1990 to 1998 the Liberal Party occupied the presidency of the country. Period during which the public institutions in charge of promoting women's rights and eradicating their discrimination were created, thus fulfilling the CEDAW. Initially, in 1992, the Presidential Council for Youth, Women and the Family was created. This Council designed the Comprehensive Policy for Colombian Women (CONPES 2626), the first national policy for all women. It sought to improve their living conditions and strengthen the process of their participation and organization. It concentrated its resources on the care of poor women in marginal rural and urban areas (DNP, 1992). During this period, the policy was decentralized, creating institutional spaces in departments and mayor ships, to a total of 19 regional offices (Londoño, 1995). In addition, the Ministry of Health approved the Policy "Health for Women, Women for Health" (Resolution 1531 of 1992).

In 1994, the Presidential Council for Youth, Women and the Family designed a new public policy called Policy for the Equity of Women (CONPES 2726). Based on the principle of equity ${ }^{1}$. The policy sought to settle the social debt with women. To that end, among others it proposed the objectives of fostering a permanent debate on the situation of women; inform and make the society aware of the contributions of women and the negative social costs of their subordination; incorporate the principles of equity and participation in the National Development Plan (PND); promote equal opportunities; integrate women in the universalization of health services, education and employment programs; avoid discrimination in the provision of services; and implement programs for the poorest doubly marginalized women.

The strongest public mechanism created in Colombia was the Directorate for the Equity of Women (DINEM), approved by Law 188 of 1995. Its creation was conceived within the National Development Plan (Plan Nacional de Desarrollo - PND) for that legislature. PNDs are the national public policy planned by the elected government. In that plan, DINEM was conceived as a body with administrative autonomy and its own assets, in charge of developing the participation and equity policy for women. Its director would be part of the board of the National Planning Directorate (DNP), so that it could have influence on the planning, monitoring and permanent coordination of the actions of the different entities of the state. This was the first public institution with a cross-sectorial nature responsible for promoting gender equity. At the proposal of the liberal senator Piedad Córdoba, Olga Amparo Sánchez was appointed director of DINEM. She is a renowned feminist who founded in 1982 the Women's House (Casa de la Mujer) organization. In 1997, DINEM made a series of adjustments to the previous policy, which got funding through CONPES 2941.

With the change of government in 1998, the institution for women's equity and the public policy of equality suffered an important setback. By Presidential Decree 1182 of 1999, Andrés Pastrana downgraded the status of the Directorate to Presidential Counseling, creating the Presidential Office for the Equity of Women (CPEM). This entailed the loss of autonomy, budget and participation in the CONPES. Elsa Gladys Cifuentes, coming from politics, was appointed Counsellor. During this mandate the Plan for Equal Opportunities for Women was drafted. This policy was never approved or endowed with funding. So, the institution could barely continue with some previous programs.

In 2002 the new president Andrés Uribe, also conservative, did not provide budget for the institution. Through Decree 519 of 2003, the CPEM, among its functions, has to channel resources from international cooperation in order to develop projects aimed at guaranteeing the participation of women in the social, political and economic

\footnotetext{
${ }^{1}$ Most Public policies for the social advancement of women in Colombia have been called equity policies for women. In Latin America equity is more commonly used than equality when referring to gender policies. Gender equity is created by building equal relationships between women and men including acknowledging and accepting their differences, recognizing their dignity and equal rights, as well as women's contributions to development and social welfare and the inequalities that affect them (CPEM, 2012).
} 
sphere. As well as promoting the incorporation of the gender perspective in the formulation, management and monitoring of policies, plans and programs in national and territorial public entities. Martha Lucia Vazquez, specialist in women and gender, was appointed as Counsellor. During two mandates, the Women Building Peace and Development Policy was drafted and implemented. This was based on the coordination of programs, projects and actions with other ministries and state entities, in charge of their sectorial budgets. The Ministry of Social Affairs drafted the National Policy on sexual health and reproduction (2003). These two legislatures were important in the legislative field.

The president elected in 2010, Juan Manual Santos, by Decree 3445 of 2010, elevated the institution to High Presidential Council for Women's Equity (ACPEM). This did not entail autonomy or own budget; however, the new rank of the mechanism conferred the new High Counsellor Nigeria Rementería, lawyer and expert in differential approach, greater power of interlocution with the rest of the ministries, with a seat within CONPES. During this period, the Ministry drafted the Guidelines of the National Public Policy on Gender Equity for Women (2013). This policy contained the Guidelines for a Comprehensive Plan to Guarantee Women a Life Free of Violence (2012-2022), with a completion time of ten years. The CPEM also drafted the Guidelines for the Prevention of Risks, Protection and Guarantee of the Rights of Women Victims of Armed Conflict (2013). These policies were endowed with funding through their approval by CONPES, documents 161 and 3784 respectively. In the second term of Santos, by means of Decree 149 of 2014, the mechanism was renamed again as Presidential Counseling Institution for the Equity of Women, losing its seat in the CONPES. The current counsellor is Martha Ordoñez, a lawyer and defender of women's rights.

\section{Discussion and conclusion}

Firstly, on one hand, since the eighties, the majority of presidents of the country, with the exception of the legislature of Ernesto Samper, have promoted peace processes and policies, with a different approach, establishing negotiations with different armed actors, either revolutionary or paramilitary. On the other hand, in the eighties as well, first policies for the advance just of peasant women were drafted. It can be observed that after the approval of the new constitution of 1991, a will to strengthen gender equality in the country was born, through the development of mechanisms and policies, according to the international commitments for women's advance in the world. However, since the last nineties, while peace processes with different actors were promoted, equality policies suffered a serious cut-off. Between 1998 and 2012, for a period of fourteen years, equality was not a real priority reflected in strengthening gender policies through specific funding. In the 20142018 term, this seemed to be reversed, upgrading the mechanism and giving funding through CONPES. But subsequently there has not been a renewal of said will while the current legislature.

The institutional mechanism in charge of promoting equality of women in the country had the greatest decisionmaking power during a short period, from 1995 to 1998, when DINEM was created. From its degradation to Counseling, its administrative autonomy and own patrimony were annulled, as well as its participation in the National Planning Council of Economic and Social Policy. The functions of the institution were conditioned to negotiations with other ministries, arranging actions and the assumption of them from sectorial budgets. But with the difficulty that entails the lack of institutional range of the CPEM to reach agreements. As Martha Cecilia Londoño (2006) pointed out, the weakness of the institutional framework for equality in Colombia is related to the dependence of the will of the current government. Different governments have restructured the entity, generally with a downward status. The change of personnel and renewal of the workforce with each governmental change has hampered the continuity of the actions and objectives previously proposed.

Secondly, there is a correlation between the range of the mechanism and the funding of the drafted policy. In fact, during the period in which the mechanism was counseling, no specific budget was approved for the drafted policy. The budgetary allocation was given again when it was promoted to High Counseling and the High Councilor had a seat in the CONPES again. The range has not been maintained since 2015. The CONPES 161 
does not offer any information on the equity policy funding from 2017. Despite the fact that the Comprehensive Plan to Guarantee women a life free of violence, valid for ten years (2012-2022), is part of it. On the other hand, in the public policy Guidelines for the Prevention, Protection and Guarantee of the Rights of Women Victims of Armed Conflict, it is established that funding will be charged to each of the sectors of the State involved: mainly to Social Inclusion, Housing, Judicial Branch, Domestic Agriculture, Labor, Education and Health. Commerce, Justice, Presidency, Defense and Culture would contribute in lesser measure (CONPES 3784). According to Londoño, the lack of funding for equality policies and their progressive cutting have made the dialogue with women's movement in the country difficult. Obviously, the mechanism has not been able to guarantee a consistent and effective equality policy. Due to these factors, low institutional range, low budget and lack of continuity, equality policies have had a low impact and have been insufficient to generate transformations (Londoño, 2006).

Thirdly, there is a relationship between the ideology of the elected government and the strengthening or not of the equality policies and mechanisms for equality at the national level. It can be observed that the institutional mechanism for the equality of women has been created or reinforced mostly during the mandates of liberal governments and degraded during conservative mandates. The same can be observed in relation to the funding of the drafted policies. During the mandates of conservative governments, cuts have been applied to the institutional mechanism and the principle of mainstreaming gender policy has been used to justify the financing of equality policies from sectorial budgets, without assuring or specifying the amount that ministries had to contribute with.

Different governments in Colombia have made important legislative efforts to promote women's rights, but this has not always been accompanied by specific funding to implement public policies, such as plans, programs, services, projects and campaigns supported by the executive power. The trend points out the practice of funding equality policies transversally with charge to sectorial policies, without specifying budgetary commitments in the medium term.

Fourthly, regarding the relation between peace and equality, in the analysis of the evolution of the mechanisms and public policies for equality in Colombia, an asymmetric relationship can be seen between the governmental efforts for peace achieving and gender equality promotion in the country. Peace and equality have not worked as a pair of inseparable values. Conservative presidents reduced equality policies to a minimal expression, despite their aspirations for peace and equality provided for in the National Plans for Development. This could be related to the concept of negative peace, just the defeat or demobilization of the armed actors, instead of a positive peace associated with social justice (Galtung, 1969), and consequently gender equality. Positive peace, understood as a social process of truth, social justice, reparation of victims and guarantees of non-repetition, must be accompanied by investment in equality as well. It is important to pay attention to this reality, since peace processes can lead to state marginalization of gender equality and equity policies, as we have observed in the case of Colombia.

The peace process will not necessarily entail and increase social investment and equality policies. In Colombia, coinciding with peace processes, the institutional mechanism created to promote equality was reduced. Despite the fact that the driving mechanism was subscribed to the government's presidency, the lack of autonomy, decision power and budget affected negatively the achievement of the functions given. Although the functions of the institution were maintained, it was not endowed with the rank, patrimony and administrative autonomy that would have allowed it to lead processes, negotiate the mainstreaming of policies within ministries and reinforce local equality policies. In fact, according to the Spanish Agency for International Development Cooperation (AECID), in 2011 only 13 out of 32 departments and 5 city halls in the country had Equality Secretariats or other type of office (AECID, 2011), a number lower than the one mentioned by Londoño respect to 1995 . 
Sixthly, an institution reduced in patrimony and autonomy entails insufficient personnel to carry out the functions that correspond to the mechanism, including the necessary intra governmental awareness. In addition, technical knowledge, policy continuity and increasing effectiveness possibility are lost. Likewise, government increases the distance from the women's movement, which cannot see in the mechanism a valid interlocutor that can respond to their demands. Although equality is a constitutional principle, the policy of equality in Colombia does not respond to a long-term State pact, in compliance with ratified international commitments. Instead, the commitments are variable depending on the governments and their priorities. Gender inequality is relegated to a second-order issue. In addition, despite the quota law, the figures for women's political participation are far from the $30 \%$. In the electoral organization they represent $23 \%$ and in the positions of political appointment the average is 28\% (Humanas, 2017). Therefore, its influence on decisions of the government of Colombia is limited.

Finally, I would like to draw attention to the fact that the mainstreaming of gender policies can become the justification for not giving specific budget to the mechanism of equality and the drafted policies. On the one hand, it is necessary to provide financing in order to create a strong institution with status and sufficient technical personnel competent in the matter, who can design inter sectorial policies with other ministries and governments. On the other hand, it is also necessary cross-sectorial financing for the development of services, programs and projects, which must be committed from the general budget of the State, beyond the financial support of international agencies. In that regard, the United Nations Security Council, as was pointed out in the Beijing Platform for Action, should pay attention to the institutional strengthening of gender equality mechanisms and policies in countries in situations of armed conflict and post-conflict. It is necessary to overcome the funding approach of programs and projects to promote solid institutions with medium-long term national plans endowed with a budget.

\section{Reference}

AECID (2011) Ciudades e igualdad de Género. Boletín, 6.

Águila Rubín, Marcela (September 30, 2016) “¿Para qué una consulta si hay una solución única”.Swissinfo.ch Barrios Escalante, Sergio (2016) "Colombia en su laberinto". América Latina en Movimiento.

Cardona, Jorge; González, Carolina (June 22, 2016) "El camino hacia la paz con las FARC" Chapter 1. El espectador.

Chaparro, Natalia (2013) Amnistía e indulto en Colombia: 1965-2012. Faculty of Right and PoliticsSciences. Universidad Nacional de Colombia.

CPEM. Mujeres constructoras de paz y desarrollo. Una política nacional orientada a la paz, la equidad y la igualdad de oportunidades 2003-2006.

Galtung, Johan (1969) Violence, Peace and Peace Research. Journal of Peace Research, Vol. 6, No. 3, pp. 167 191.

Herrera, Camilo (June 26, 2016) “QQue clase de político es Juan Manuel Santos?” El tiempo Blogs.

Humanas. Compliment of Colombian State with Resolution 1325 of 2000. Report 2016-2017.

DNP (May 17, 1984) Política sobre el papel de la mujer campesina en el desarrollo agropecuario. República de Colombia, Departamento Nacional de Planeación.

DNP (November 23, 1992) Política social para los jóvenes y las mujeres. República de Colombia, Departamento Nacional de Planeación.

DNP (January 21, 1994) Política para el desarrollo de la mujer rural. República de Colombia, Departamento Nacional de Planeación.

DNP (August 30, 1994) Política de participación y equidad para la mujer. República de Colombia, Departamento Nacional de Planeación.

DNP (August 13, 1997) Avance y Ajustes a laPolítica de participación y equidad para la mujer. República de Colombia, Departamento Nacional de Planeación. 
DNP (March 12, 2013) Equidad de género para las mujeres. Documento CONPES Social 161.

DNP (November 25, 2013) Lineamientos de Política Pública para la Prevención, la Protección y la Garantía de los Derechos de las Mujeres Víctimas del Conflicto Armado. Documento CONPES Social 3784.

Grabe, Vera (2004) “Los procesos de paz 1990-1994”. ConciliationResources, Procesos institucionales de paz 14 , pp. 40-46.

Indepaz (February 25, 2018) "Homicidio de defensores y defensoras de paz; una tragedia que no se detiene". Instituto de Estudios para el desarrollo y la paz.

Londoño, Martha Cecilia (1995) "Políticas estatales para la equidad". Universidad del Valle. Revista Perspectiva, 2.

Londoño, Martha Cecilia (2006) "Equidad de Género y Políticas Públicas”. Revista Colombiana de Trabajo Social, 20, pp. 179-192.

Montoya, Ana Milena (2009) "Recorrido por las políticas públicas de equidad de genero en Colombia y aproximación a la experiencia de participación femenina con miras a la construcción de escenarios locales". Estudios de Derecho, Vol. LXVI, 147, pp. 305-319.

Oion Encina, Rakel (2003) Las mujeres en Colombia por la paz [Master thesis]. Universidad Complutense de Madrid. URI http://hdl.handle.net/10810/16078

Osborne, Raquel (2000) La violencia contra las mujeres. Realidad social y políticas públicas. Madrid, UNED.

Prieto, Jineth (April 4, 2016) “EPL: ¿El heredero de las Farc y el Eln?” Santandereana.

Rehm, Lukas (2014) "La construcción de las subculturas políticas en Colombia: los partidos tradicionales como antípodas políticas durante La Violencia”. Historia y Sociedad 27, pp. 17-48. 